\title{
Pedagogies of transformation: keeping hope alive in troubled times
}

\section{Terry Wrigley, Leeds Metropolitan University, Bob Lingard, The University of Queensland and Pat Thomson, The University of Nottingham}

\begin{abstract}
This paper seeks to challenge the view that there are no alternatives today to global neo-liberalism and its manifestation within schooling systems and educational practices, particularly as high stakes testing and reductive pedagogies and curricula. The paper challenges the fast and shallow learning endemic to these practices, arguing instead for a different temporality of learning and school change. Indeed, the paper argues that there is a pressing need for progressive educational change and that ideas are an important component for such change and for rethinking practices, although not enough in and of themselves. The paper works with a broad Enlightenment construction of pedagogies and a conception of school reform framed by values of democratic citizenship and social responsibility, and the need to connect with school communities, especially those communities disadvantaged by contemporary economic and policy settings. In disadvantaged communities, schools and teachers need to work with community funds of knowledge to scaffold to valorized high status school knowledge. The school also needs to function as a quasi democratic polis, while the reach of curriculum needs to be global. The focus of the paper is thinking about new pedagogies of teaching and school change as resources for hope.
\end{abstract}

\section{Key words}

\section{world crises, pedagogies, school change, authentic learning, hope}

What the best and wisest parent wants for his (sic) own child, that must the community want for all its children. Any other ideal for our schools is narrow and unlovely; acted upon, it destroys our democracy. (John Dewey, 1990, p.3)

\section{Introduction}

It is difficult to change things if you do not believe you can. It should not surprise us, therefore, that proponents of neo-liberalism have repeatedly sought to legitimate and extend their agenda through claims that there are no other possibilities. Claims such as that we have reached the 'end of history' (Fukuyama, 1992) work to create an illusion that we are living in a 'dictatorship of no alternatives' (Unger, 2005). Globalisation is presented as an inevitability which renders futile the struggle for improved living conditions, a welfare state or the capacity to produce what people need. This is not a social science understanding of globalisation, but rather a 'performative use', as Bourdieu (2003) put it, meaning that globalisation is equated only with one set of political possibilities, while others are obliterated. This discursive sleight of hand has powerful 
political effects. All sense of historical time is blurred by the frenzy of production and consumption under fast capitalism (Meszaros, 2008). Even after the banking crisis, politicians tell us the only way out is more of the same..

Education too has suffered from the corrosive power of a supposed 'inevitability'. British Prime Minister Tony Blair argued from his election in 1997 that globalisation placed such constraints on the nation state, challenging its economic sovereignty, that a government's major influence on the economy was through education:

Education is our best economic policy... This country will succeed or fail on the basis of how it changes itself and gears up to this new economy, based on knowledge. Education therefore is now the centre of economic policy making for the future. (Blair, 2005)

As a consequence, educational policy was redefined to serve economic interests. As Ball (2008) succinctly observes,

The social and economic purposes of education have been collapsed into a single, overriding emphasis on policy making for economic competitiveness and an increasing neglect or sidelining (other than in rhetoric) of the social purposes of education. (Ball, 2008, pp.11-12)

In England, as in many other jurisdictions, centralised control over the school curriculum and the use of approved teaching methods have been sustained through various forms of surveillance and audit, with high-stakes assessment intimidating teachers and framing learners as passive recipients of imposed knowledge. At a policy level, educational achievement has been redefined as 'effectiveness' within the terms of competitive market systems, and official versions of 'school improvement' have served to occlude the spread of alternative visions (Wrigley, 2003).

But when all is said and done, change happens. In the wake of the banking crisis, the past year has been marked by revolutionary movements across the Middle East and waves of protest sweeping back and forth across much of Europe and North America. Young people have been particularly affected by the crisis, with youth unemployment reaching 20\% in Britain and 45\% in Spain: they are fast learning how to resist.

Innovation also continues to occur in the field of education. We (Wrigley, Thomson and Lingard, 2012) have recently published an international collection of case studies, entitled Changing Schools, which documents the practices of reforming schools, progressive ideas in practice, as it were. Our aim was not only to show the reality of curricular, pedagogical and institutional innovations, but to understand the modes of school development which enable and sustain them. The various papers in this special issue of Critical Studies in Education, though not based in schools, continue that essential work of rethinking school change: ideas for practice. The papers in this volume are not, generally, based on practice which is well established in specific schools or networks, but such utopian thought-experiments and theoretical explorations play an important role in transcending the normalities of standardized schooling.

As Unger (2005, p.1) puts it: 
The world suffers under a dictatorship of no alternatives. Although ideas all by themselves are powerless to overthrow this dictatorship, we cannot overthrow it without ideas.

Michael Fielding and Peter Moss (2011), in their recent book Radical Education and the Common School, argue the importance both of developing principles and theories and of demonstrating through real examples that alternatives are viable. They suggest that this involves an imaginative rethinking of alternatives, but also a look backwards to draw on a rich legacy of progressive and critical education (Fielding and Moss, 2011, p. 3).

We believe that our book also achieved these aims, and that the various papers in this special number of Critical Studies in Education, whilst drawing on progressive practice as well as sharp critique, complement it by expanding theoretical horizons. Rather than writing a commentary on the other contributions to this special issue, we are using this opportunity to develop and share our own thoughts.

\section{The larger and lesser crises}

School change cannot be divorced from the wider challenges facing our world: environment, war, poverty, finance. As young people are often aware, these various crises interconnect. Climate change and the degradation of land, poverty and war are actively produced by the dynamics of global capitalism. The world's owners, relentlessly chasing profits, are acting as if there is no tomorrow.

Its owners treat the planet as if it could be discarded, a commodity to be used up... But what other world are we going to move to? Are we all obliged to swallow the line that God sold the planet to a few companies because in a foul mood he decided to privatize the universe? (Galeano, 2000, p.267)

The predominant educational response to the elevation of economic greed above all else has been to work within it and service it: to transmit commodified instrumentalist knowledge within business oriented, and even commercially owned and managed, schools in a competitive market system. It has taken some time, but we believe there is now a growing revulsion against such a model. Individuals pursuing their own self-interests with no concern for the common good do not produce a good society. At the classroom level, no amount of imposed discipline can override the need to engage with the multiple and overlapping issues facing young people: the accelerated cultural change caused by the very rapid development of information and communication technologies, global migration, a resurgent desire to assert their citizenship, and the hybrid stylistic dynamism and diversity of youth cultures.

The three of us have written extensively from a concern that the dominant regimes of change facing schools in recent decades do not live up to the complexity and fluidity of the situation (e.g. Lingard et al., 2003, 2008; Thomson, 2002; Wrigley, 2003). Policies barely engage with the complexities faced by schools; official attempts to 'improve schools', which are largely concerned with maintaining traditional practices but with added efficiency, simply do not meet the needs of individuals, communities or nations in the twenty-first century. Additionally, improvement is reduced to improved test results and an upward 
form of accountability, which denies professional responsibility to teachers and eviscerates debate about purposes (Biesta, 2004).

Paradoxically, we now find our sense of radical doubt echoed by some voices from the political right - see the review in this volume of Diane Ravitch's Death and Life of the Great American School System (2010) in Wrigley's essay review. From a deeply traditional perspective on knowledge, Ravitch perceives that instrumentalist short-term cramming to satisfy the gluttonous appetite of the national testing machine produces only a parody of education. Despite the official rhetoric of 'raising standards', education is trivialized, literacy treated as a technical matter disconnected from pleasure and purpose, and knowledge passed on as a set of inert facts which are sensed to be of limited consequence to the individual and/or society (Wrigley, 2006a, pp.8-9). Albeit from different political positions, we share Ravitch's belief that schooling must also be about citizenship and community - without it we risk social disintegration.

Though globalisation has been the most prominent keyword of policy studies for over a decade, we wish to reassert the centrality of class. It is not the planetary scale of modern economies, communications and cultures which is the problem, but the global dominance of capitalism, particularly in its fortified neoliberal version, and the gross inequalities and injustices that it produces.

By class, we do not mean primarily the binary of middle versus working class, which has dominated sociology of education for half a century, nor even the important emphasis upon social reproduction seen in terms of relative 'middle class' advantage. Constant reiteration of this particular binary allows what we might call a ruling capitalist class to escape from view. It allows us to forget that the children of teachers and computer programmers are also not well served by a system designed for the more efficient production of 'human resources'. Though there are doubtless differences in the ways they experience and participate in schooling, the children of manual, routine white-collar and professional workers - winners as well as losers in the academic race - are all suffering from the modes of teaching and learning which neoliberal pressures reinforce. Though this is a rarely mentioned aspect of class reproduction, too much traditional school learning has taken the form of alienated labour. Rather like factory work, students are told what to do and how long to do it for; they hand over the product not to a real user or audience, but to the teacher as assessor, and in exchange, the teacher gives back a mark - a kind of surrogate wage. Learning seems to have exchange value, but rarely a use value (Wrigley, 2006a, p.105).

\section{Pedagogies of enlightenment}

Worthwhile school change is a pedagogical issue. Organisational change must serve pedagogical ends and be pedagogical in approach. Genuinely educational leaders work pedagogically with other teachers and the wider community to support their learning. Good schools are 'saturated in pedagogies' (Thomson, 2001).

This is to use pedagogy in its Enlightenment sense of educating for human development - helping young people to become more fully human, individually and collectively. Pedagogy is always grounded, though it aspires to a quality and condition of life which transcends its starting point. It expands the individual's 
possibilities - economic, social, aesthetic, moral - and helps to 'constitute a new social imaginary, an imagined better future, locally, nationally and globally' (Wrigley et al., 2012, p.196).

The test-driven accountability systems of recent decades have reinforced a view of school learning as the memorization of emaciated facts and the development of cognitive capacities which are divorced from real-world significance. This is contrasted with a version of vocational training based on the acquisition of practical skills through imitation. Some of the most interesting curriculum development we have seen has bridged this gulf to connect theory and cognition with experience, and critical thinking with social engagement. This is not to deny that thinking sometimes requires a quiet place free from distraction, nor to devalue abstract knowledge, academic disciplines or indeed the repetitive practice of a technique. However, for many learners, these acquire significance and foster motivation better when related to socio-cultural purposes and contexts.

Our view is not only a response to new developments in the psychology of learning, built around concepts of situated cognition and sociocultural theory (e.g. Robbins and Aydede, 2009; Perkins, 1992; Salomon, 1993); rather we also believe that inherited (default) practices of schooling must change because they do not help produce human beings with the resources to live fruitful lives in today's globalized world. As well as excluding large numbers of young people from engagement with learning and valuable qualifications, inherited ways of being teachers and 'doing school' are unconducive to social transformation, either on a local, national or planetary scale. All of this, of course, is within a context of compound global crises, which do indeed demand a rethinking of pedagogy and of the broader purposes of schooling.

Pedagogy is bigger than methodology: it involves reflecting on society, values, history, environment and learning itself, but forming theories about pedagogical transformation is empty if we do not also address specific approaches to teaching and learning.

Moreover, there must be no trade-off between care and intellectually challenging curricula (Lingard, 2007). Deep care is central to socially just pedagogies, which understand the need to scaffold from where students are at, respecting their existing knowledges, while at the same time making available the high-status knowledges traditionally valued in educational systems. This involves a commitment to epistemological inclusion: effective pedagogies are contextualized and connected to students' lifeworlds, whilst stretching beyond these in educative ways: community funds of knowledge meeting valorized cultural capital.

A search for greater relevance is not enough, nor the proposal that learning become more experiential; both can mean an uncritical assimilation to the status quo. We prefer connectedness to relevance because it indicates both a respect for students' knowledges and interests and the need to scaffold learners into other knowledge forms, genres and media from which disadvantaged students should never be excluded.

We need to develop enhanced forms of learning environments - real learning communities - to produce high-quality cognitive development, education for 
citizenship, authentic motivation, and engagement with knowledge that is more than a drizzle of dusty data and mind-numbing worksheets. Such enhanced environments produce learning which is simultaneously grounded and critical. Beyond the progressive tenet that learners should have opportunities to pursue their own interests, many of the chapters in our recent book place the focus on young people's concerns (Beane, 1997).

In order to develop pedagogies based on a collective construction of knowledges which are grounded in the learner's lifeworld and rooted in place and identity, we need to become more explicit about whose knowledge counts. The terms 'funds of knowledge' (Moll and Greenberg, 1990) and 'virtual school bag' (Thomson, 2002) point to the importance of understanding community-based, popular, and extended cultural knowledges and youth cultures as assets that are normally discounted. These other knowledges need to be mobilized and converted into 'symbolic capital' (Bourdieu, 2004). This proposition runs counter to standard educational processes whereby working-class and Indigenous cultures are misrecognized and excluded, and only professional and higher class cultures and knowledges are ratified and become 'cultural, social and symbolic capital' that advantages some and disadvantages others (ibid).

It is crucial for educators to work in zones of connection with their local communities, in order to help students develop thoughtful and well-considered responses to their situations and surroundings. In some cases, this involves realworld problem solving, whilst in others teachers provide an 'offline' environment for simulated participation, with or without the aid of ICTs.

Place-based learning (e.g. Gruenewald and Smith, 2008) is one such movement. This involves context not simply as motivation, but as the foundation for cognition and reflective action, and with a strong aesthetic and affective dimension. The exploration and direct appreciation of local environments is a necessary means towards gaining a sense of planet Earth, but in addition to firsthand visual experience, place-based learning can also involve imaginative visualisations, thought experiments and tactile rituals, as well as computermediated access to distant places in tandem with young people on other continents (see Wrigley, Thomson and Lingard, 2012, chapters 8-11).

In the drive to make schools more 'effective', too much emphasis has been placed on increasing the pace of teaching and learning. In some education systems, standardization of curriculum places pressure on teachers always to hurry onto the next item on the syllabus; here coverage takes precedence over deep understanding. Deep conceptual learning takes time - this is 'slow learning' (in a sense akin to 'slow cooking') as opposed to the more superficial fast learning aimed at improved test scores. A more extended and flexible timeframe is needed to allow learners more control over activities. More open architectures of learning can involve, for example, creative projects leading to an open exhibition or performance for parents in the tradition of Dewey; project method, based on an agreed problem or issue; the engagement of learners in resolving a real-world problem; or storyline, a form of thematic work based on the outline of a narrative.

Critical thinking can be promoted in many different ways. Problem solving is central to the transformation of mathematics, used as a tool for critical 
understanding of injustice (see Gutstein, 2006); to the initiation into philosophical questioning (e.g. Lipman, 1988); and to critical literacy (e.g. Janks, 2010). But criticality is not enough if we wish to develop a spirit of hope. The arts, including collaboration with creative artists and practitioners, are unduly neglected in efficiency-driven curricula, but can play an important role here, providing not only satisfaction through personal expression and presentation to an audience, but a creative space in which alternatives can be imagined to present ways of living (Sefton Green, Thomson, Jones and Bresler, 2011).

As we argued above, this is not to neglect the formal knowledge deriving from academic disciplines, which provide learners with the conceptual and linguistic tools to name and frame their experiences in new ways and open doors to alternative perspectives on reality. Bringing disciplinary knowledge together with the life experiences of learners was strongly advocated by Dewey (1938), who saw experience and curriculum coming together to produce 'real' learning, rather than being kept apart as polar and irreconcilable opposites. This also accords with Vygotsky's (1978) social constructivist theory that language and other symbolic systems - our cultural inheritance - operate as tools for understanding. It also relates to Bhaskar's (1975) argument for critical realism that the surfaces of phenomena may not of themselves reveal the deep structures and laws of reality. All of this connects with the Freirian tradition of re-presenting to learners aspects of their daily lives and helping learners to analyse them in ways which reveal causal relations of injustice as part of the conscientization central to pedagogies of hope (e.g. Freire, 1972).

\section{Systems, structures and change processes}

Probably the most important conclusion from the substantial international research on school change is that sustainable and meaningful change requires the full professional participation of teachers and other staff, extended to recognize the rights of students and parents. There is also broad agreement on the importance of staff development, collaboration in strategic planning, revising plans as you go, ongoing evaluation, and so on.

Of the utmost importance are teams of staff who can collaboratively design the curriculum and teaching approaches besides evaluating the benefits and drawbacks of change processes and outcomes. Such teams have a strong ownership of the change process they are pioneering, but link strongly to wholeschool gatherings and representative groups so that they have a clear sense of the direction and aspirations of the school as a whole, including wider community involvement.

Unfortunately, much of the literature has failed to examine seriously the social and cultural situations in which schools operate. There has also been a tendency among experts on leadership and school improvement to ignore all the other fields of educational knowledge concerning curriculum, pedagogy, inclusion, school ethos and community links. The term 'leadership' has become extremely problematic, despite recent extensions towards 'distributed leadership' or 'teacher leadership'. In its vernacular sense, leadership involves recognising the dangers of the place where you are and having a sense of where you might move and how to get there. Despite the frequent use of words such as 'vision' and 'values', this sense of direction is absent from much of the current leadership 
discourse. It often seems as if any old vision and values will do. Worthwhile change requires a perception that schools must be different because the world must be different, and a recognition that schools can and must contribute to this wider change.

The overwhelming emphasis over the past twenty years on individual schools as the loci of change has been valuable but also problematic. This emphasis arose from a realisation of the difficulties in disseminating large-scale curriculum reforms, but is now operating in many countries in a marketised environment consisting of schools which are in competition with each other. School improvement experts such as David Hopkins (in Pont et al., 2010) are currently struggling to reconstruct 'systems leadership' in contexts where the old systems (local education authorities, non-punitive state inspectorate, curriculum development projects, school systems etc.) have been wiped out, and where coherence of local provision is being undermined by various forms of privatized management. This is particularly the case in England (Hatcher and Jones, 2011, Lingard and Sellar, in press). In our view, however, the real challenge is to find ways of rebuilding supportive systems of public education, which work democratically to engage with community needs and to support civic aspirations.

Alongside the necessary on-site participation in school change, we regard engagement with wider networks of educational reform as a vital stimulus and support for change. Traditionally, this included inter-school collaboration within local education authorities and regions, and we continue to insist on their value, but also recognize the possibilities of wider networks of educational reform, which can now stretch electronically across the globe. Networks may be formally established or develop informally as the result of mutual visits; they can be built on research and sharing practice, or be grounded in an existing social movement. In all circumstances, however, it is clear that practical breakthroughs arise from intellectual struggle and critical reflection, not from association alone. Such networks require both the sharing and development of a common pedagogical and social vision, and the flexibility that arises from recognising that each school has its own path of development. This is the 'thisness' of each school (Thomson, 2002).

Innovative teachers see themselves as knowledge builders, engaged in practitioner research, and in some cases writing and publishing for others. However, more radical change also requires the resources of a wider body of theory. The theories developed by educators in the past, themselves engaged in a struggle to make education more meaningful, are a vital resource for changing schools today. Such theory, along with inspirational examples of change, provides a vision of alternative ways of organising schools, and aids the deep questioning which is integral to building a shared sense of educational purpose. Shared leadership - which means more than administrative delegation - must be constructed around an agreed philosophy of learning. Such a philosophy must also underpin school as learning community.

Transformational change requires us to consider structures as well as cultures. One of the biggest challenges concerns the norm, in many countries, of secondary schools with a thousand or more pupils. Secondary schools in Scandinavia, on the other hand, are generally small: indeed the average size in Finland is only 
300. This brings considerable benefit in terms of developing trust and relationships with pupils and parents (social capital, if you like), as well as teamwork among staff. In Norway, the standard arrangement is for a year group of 60-100 pupils, taught by a team of 5-6 teachers. This same team also provides pastoral care, attends to learning difficulties and personal difficulties, and relates to parents. Such an arrangement makes cooperative development and operation of the curriculum much easier. In the USA there has been some turning away from large high schools towards small schools and schools within schools, though much of this has been entangled with privatisation of educational governance. Networks such as the Coalition of Essential Schools (www.essentialschools.org) have promoted school restructuring, based on the need to reduce the number of teachers that each class encounters, as well as the number of students that each teacher must relate to.

Culture is a keyword in much of the school change literature, but frequently interpreted in limited instrumentalist ways. While we readily acknowledge the complexity of the concept, culture is crucially about the visible and habitual ways in which meanings are shared. This necessitates a careful consideration of everyday actions, interactions, discourses, visual displays, and so on, as they impact on learning, social justice and preparation for citizenship. For example:

- examining the cultural messages of classrooms dominated by the teacher's voice, closed questions and rituals of transmission of superior wisdom

- questioning the culture of target setting and surveillance, and exploring more fruitful forms of educational responsibility than the present accountability systems

- understanding how assumptions about ability and intelligence impact on classroom interactions

- discovering how prejudicial assumptions about single parents, ethnic minorities and 'dysfunctional' working-class families operate symbolically in staffroom interactions. (see also Wrigley, 2003, pp.36-7)

Blackmore and Thomson (2006) have argued for the need to go beyond notions of structure and culture to consider the concept of school redesign ${ }^{1}$, a process which works with existing aspects of education but remodels their various modalities, including key organizational issues such as space/time and associational and aesthetic practices. They take an ecological view of schooling, and suggest that change must be holistically and realistically conceived as the continuous working through of principles in and as thoughtful conversations.

Schools in disadvantaged areas in particular need a greater coherence and mutual understanding between staff and parents. This is not helped either by stigmatizing descriptions of these neighbourhoods, or by accountability systems which involve 'naming and shaming' schools with relatively low attainment. These practices inevitably lead to demoralization and instability of staff. In such a context it is particularly important to identify key individuals who can connect

\footnotetext{
1 This is a concept of design that recognises the agency of actors. In this way, it is very different from the concept of design and a conception of the population as 'designed', which the cultural critic Hal Foster (2002) has written about almost as a dystopia, a world of 'total design' from designer genes to jeans and an extreme of consumer capitalism.
} 
the school to the wider community, as well as seeking out new ways of involving parents and community members in school learning.

\section{Social justice at the heart of change}

Fraser $(1997,2000,2009)$ argues that the struggle for social justice involves various combinations of redistribution, recognition and participation. Even in the case of poverty, which clearly requires economic solutions, the hurt done by discourses of denigration to poor ethnic minority groups is substantial (see, for example, Jones, 2011).

As Fraser explains,

As a result of repeated encounters with the stigmatizing gaze of a culturally dominant other, the members of disesteemed groups internalize negative selfimages and are prevented from developing a healthy cultural identity of their own. (2000, p.109)

This clearly has major implications when we consider the reasons for the relatively low achievement of young people growing up in poverty. As Charlesworth (2000) and others show, the experience of long-term unemployment and insecure work in deindustrialized areas generates deep feelings of (i) shame, as people internalize their situation; and (ii) futility, as they realize that plans simply do not reach fruition and further training does not bring them work. It is important to understand how these emotions are often reinforced by traditionalist patterns of schooling, for example through placement in 'low ability' groups or the imposition of tedious and unchallenging work. In such contexts policy which talks of lack of aspiration is 'symbolic violence' (Bourdieu, 2004).

The regular and exhausting student-teacher conflicts in schools in disadvantaged areas are saturated with young people's perceptions of disrespect and stigmatization. Students quickly come to understand themselves as surplus in schools where exclusions are common; this directly connects with a society where (in the UK, at the time of writing) a fifth of 18-25 year olds are neither in work nor education / training. Sennett and Cobb (1972), in their classic book The Hidden Injuries of Class, point to the long-term damage brought about by the ways in which schooling works with ideas of children's fixed in/ability and un/intelligence. They show how aspiring working class parents often present themselves to their children as a 'warning' (a hidden injury of class and a further example of 'symbolic violence'), while middle class parents proffer themselves as 'role models'. The response needed from schools is multiple and complex, but must surely involve intensive work to create a shared sense that pupils and their worlds are respected, recognised and represented, and that school learning brings public recognition and mutual respect, as well as allowing for the voices of the many to be heard - what Fraser would see as representation. It is worth quoting this statement of aspiration agreed at a strategic German conference in the mid-1990s Future of Education - School of the Future (Bildungskommission NRW, 1995):

\section{School is a Home for Learning}

- a place where everybody is welcome, where learners and teachers are accepted in their individuality and difference

- a place where people are allowed time to grow up, to take care of one another and be treated with respect 
- a place whose rooms invite you to stay, offer you the chance to learn and stimulate you to learn and show initiative

- a place where diversions and mistakes are allowed but where evaluation in the form of feedback gives you a sense of direction

- a place for intensive work and where it feels good to learn

- a place where learning is infectious.

As this set of commitments implies, unless the ethos of a school is inclusive in such ways to all of its members, the attempt to include particular groups of students will be conflictual and frustrating. Conversely, schools that do not reach out to students with particular needs or talents are less likely to overcome rigid behavioural patterns and expectations and will be experienced as alienating by many of their other students.

It is our contention that inclusion is a central issue for school change and we agree with Roger Slee (2011) that at the same time the default impulse of many schools is one of exclusion. Just as we think a way forward for schooling demands a challenge to the default setting of classrooms, so too rethinking is required in relation to exclusion as default setting. All schools include students who are experiencing physical limitations, behavioural difficulties or emotional traumas. Schools are often operating according to assumptions about 'intelligence', which can be deeply prejudiced and prejudicial. The major divisions in society according to 'race' (including language needs), ethnicity (cultural differences), gender (along with sexuality), disabilities and social class (exacerbated in many places by extensive poverty) are reflected in complex ways in schools. A lack of commitment on these issues simply strengthens prejudicial attitudes and habits. Beyond this however, we would argue the need to reflect and debate the extent to which young people (and their parents and communities) in general, with their rich identities and cultures, are genuinely included in the school as community.

We certainly need to develop much stronger understandings and models of the school as democratic 'polis'. Schools can contribute to the formation of a polis in three major ways: by themselves functioning as democratic communities; by teaching students about the histories, philosophies and practices of democracies; and by supporting democratic actions at neighbourhood, national and even global scales. The internet and social media can certainly be a source for such democratic engagements.

Going beyond a recent concern for student voice, we need to consider how schools might foster a greater sense of agency (Wrigley, 2006b), in terms of greater direction of their own learning, participation in change within their own school, and through involvement in social change in the wider community. This has perhaps been most strongly developed so far in the Australian student action teams movement, social organizing around continued racism in the North American context and generally around the environment (see chapters 7, 8, 10 and 15 of Wrigley, Thomson and Lingard, 2012), but other examples are beginning to emerge (see for example chapters 2, 6 and 7 in Wrigley et al., 2012).

\section{Concluding thoughts: A sense of future}

In his thought-provoking book The Challenge and Burden of Historical Time, socialist philosopher István Mészáros (2008) argues that global capitalism's sense of time is focused upon 'exploitable labour time' - the insatiable drive to achieve greater profitability through more intensive and extensive production, 
regardless of human need, with a consequent loss of historical time consciousness. Thus it is no accident that neoliberal ideologists espouse slogans such as the 'end of history' and 'there is no alternative'. By contrast:

Only those who have a vital interest in the institution of a positively sustainable social order, and thus in securing the survival of humanity, can really appreciate the importance of historical time at this critical juncture of social development. ... The time of the oppressed and the exploited, with its vital dimension of the future, cannot be obliterated. It has its own logic of unfolding, as the irrepressible historical time of our age of make or break. Only the total destruction of humanity could put an end to it. (Meszaros, 2008, p 22)

This dichotomy is mirrored in paradigms of school change. The hegemonic version, espoused by many governments around the world, is based on a straightforward drive to improve test scores through intensifying learning processes and deprofessionalising teachers. It is marked by measures such as 'time on task' (regardless of the in/significance of the task) and the constant demand to raise test scores, whether or not the tests are valid or reliable. There is little sense of the longer, slower timescale of personal development and deep learning, let alone of collective historical time and human aspirations. We also note the deep temporal disjuncture between time frames for change as demanded by the political processes of elected governments and the timeframes central to real educational change. This temporal dichotomy is a central feature of both failure and resistance in policy implementation or practice.

Some schools however succeed in developing a different sense of learning time, schooling as a time for critical reflection on the world. Schools have always provided a space apart from reality: the Greek root of the word school was synonymous with leisure as opposed to work (only available, of course, to a privileged minority). At the same time, at different points in history, forms of schooling have emerged as separate places which facilitate moral engagement with the real world. These are locations from which participants are able to see beyond the day-to-day, reach to the heart of the matter, and envisage new and better ways of living. This has been true, in diverse ways, of Socrates' discussion circles, the great Islamic centres of learning and medieval universities, and the schools set up by reformers such as Owen, Pestalozzi, Montessori, Dewey and Freire.

There has been a rather polarized debate about how much difference schools can make, with some claiming they make almost no difference, but serve simply to reproduce social inequalities, and others arguing that they can make a major difference irrespective of contexts of inequality. Our position sits across this binary (Hayes et al., 2006); schools can make $a$ difference, but not all the difference; poverty and the extent of inequality have a deep and abiding impact on school learning and educational opportunity (Condron, 2011). Educational change committed to equality and a better world requires political commitments to overcoming inequality and child poverty, but schools can themselves make a difference by engaging in a politics of recognition, as well as struggling to raise intellectual challenge and avoid a 'pedagogy of poverty' (Haberman, 1991; see also Anyon, 1981). 
We certainly need less oppressive forms of system-wide accountability and more supportive policies, but some schools do manage to make a difference, even under restrictive contemporary policies, despite the greater difficulties. This crucially needs mutual support through voluntary networks and coalitions in order to avoid the erosion of what is gained. Such extended teamwork is needed to generate the complex hope that helps us create a better world. As Martin Luther King observed, 'The arc of the moral universe is long but it bends towards justice'.

This project is impossible without philosophical thinking, both in terms of reflection and debate among students and teachers, and also concerning wholeschool change. Though words such as vision, mission and values are often trivialized, the level of reflection they signal is indispensable before and during worthwhile processes of educational change. We need ideas for practice.

Philosophy involves grappling with the meanings of words and actions, the significance of everyday cultural phenomena, which we often simply take for granted, the meaning of life. This need not require a distinct or difficult vocabulary, and can be made accessible even for the very young: think of Philosophy for Children. Equally, teachers are capable of reflecting philosophically on the meaning, orientation and impact of behaviours, rituals, discourses, relationships and methodologies of teaching and learning, in relation to a wider reflection on the state of the world. This does not obviate the need to grapple with details of classroom methodology and school organisation, but without it, even meticulously planned changes will result in little more than insignificant rearrangements of inherited modes of schooling.

Paulo Freire remains a shining example of philosophy made practical in educational reform. His early work as a teacher of adult literacy, working with desperately poor agricultural labourers in Brazil, shows how discussions about basic words - home, work, landowner, hunger, city - become processes of problematization, including teasing out the threads of power which run through everyday habits and encounters. But one does not have to read many pages of Pedagogy of the Oppressed (Freire, 1972) to realize the extent to which philosophical reflection about learning and society underpins detailed thinking about teaching methods and resources.

Schooling is only one kind of education, but its role is highly significant; it can either bring about the domestication of each new generation, or launch them on paths of discovery and liberation. It can either reproduce ideologies of subordination or provide the resources and habits needed to question and move beyond them. School structures and cultures, as well as patterns of classroom language and learning, can either reinforce social inequality or challenge it.

For all of us who are concerned about the scale of crushing poverty in our own lands and across the planet; who have struggled to prevent the launching of wars which we predicted would bring mayhem; who live with a heightened sense of the fragility of our planet's ecology... education involves more than technicist versions of 'effective schooling' suggest. Changing schools is an urgent challenge, and a major contribution to (though never a substitute for) the struggle to imagine and create a better future. 


\section{References}

Anyon, J. (1981) School class and school knowledge. Curriculum Inquiry, 11(1), pp.3-22.

Ball, S. (2008) The education debate. Bristol: Policy Press.

Beane, J. (1997) Curriculum Integration. New York: Teachers College Press.

Bhaskar, R. (1975) A realist theory of science. Leeds: Leeds Books (republished 1997 London: Verso).

Biesta, G. (2004) Education, accountability, and the ethical demand: Can the democratic potential of accountability be regained? Educational Theory, 54, 3, pp.233-250.

Bildungskommission NRW (1995) Zukunft der Bildung - Schule der Zukunft. [Future of education - education of the future] Denkschrift der Kommission 'Zukunft der Bildung - Schule der Zukunft' beim Ministerpräsidenten des Landes Nordrhein-Westfalen. Neuwied

Blair, T. (2005) Speech on education, Sedgefield, 18 November.

Bourdieu, P. (2003) Firing Back: Against the tyranny of the market. London, Verso.

Bourdieu, P. (2004) The forms of capital. In S. Ball (ed.) The Routledge Falmer Reader in Sociology of Education. London: Routledge.

Charlesworth, S. (2000) A phenomenology of working class experience.

Cambridge: Cambridge University Press.

Condron, D. (2011) Egalitarianism and educational excellence. Educational Researcher, 40,2, pp.47-55.

Dewey, J. (1938) Experience and education. New York: Collier Books.

Dewey, J. (1990) The School and Society. Chicago, The University of Chicago Press.

Fielding, M. and Moss, P. (2011) Radical education and the common school: a democratic alternative. London: Routledge.

Foster, H. (2002) Design and Crime (and other diatribes). London: Verso. 
Fraser, N. (1997) Justice interruptus: critical reflections on the 'postsocialist' condition. New York: Routledge.

Fraser, N. (2000) Rethinking recognition. New Left Review, May/June.

Fraser, N. (2009) Scales of justice: reimagining political space in a globalizing world. New York: Columbia University Press.

Freire, P. (1972) Pedagogy of the oppressed. Harmondsworth: Penguin.

Fukuyama (1992) The end of history and the last man. London: Penguin.

Galeano, E. (2000) Upside down: a primer for the looking-glass world. New York: Metropolitan Books.

Gruenewald, D. and Smith, G. eds (2008) Place-based education in the global age. New York: Lawrence Erlbaum.

Gutstein, E. (2006) Reading and writing the world with mathematics: toward a pedagogy for social justice. New York: Routledge.

Hatcher, R and Jones, K (eds) (2011) No country for the young: Education from New Labour to the Coalition. London: Tufnell Press.

Hayes, D., Mills, M., Christie, P. and Lingard, B. (2006) Teachers and schooling making a difference: Productive Pedagogies, Assessment and Performance. Sydney: Allen \& Unwin.

Haberman, M. (1991) The pedagogy of poverty versus good teaching. Phi Delta Kappan, December.

Janks, H. (2010) Literacy and power. New York: Routledge.

Jones, O. (2011) Chavs: the demonization of the working class. London: Verso.

Lingard, B. (2007) Pedagogies of indifference. International Journal of Inclusive Education, 11, pp.245-266.

Lingard, B., Hayes, D., Mills, M. and Christie, P. (2003) Leading learning. Maidenhead: Open University Press.

Lingard, B., Nixon, J. and Ranson, S. (2008) Remaking education for a globalized world: Policy and pedagogic possibilities. In Lingard, B., Nixon, J. and Ranson, S. (eds) Transforming Learning in Schools and Communities. London: Continuum. 
Lingard, B. and Sellar, S. (in press) A policy sociology reflection on school reform in England: From the Third Way to the Big Society. Journal of Educational Administration and History.

Lipman, M. (1988) Philosophy goes to school. Philadelphia: Temple University Press.

Meszaros (2008) The challenge and burden of historical time: socialism in the $21^{\text {st }}$ century. New York: Monthly Review Press.

Moll, L. and Greenberg, J. (1990) Creating zones of possibilities: combining social contexts for instruction. In L. Moll (ed.) Vygotsky and Education. Cambridge, MA: Harvard University Press.

Perkins, D. (1992) Smart schools: better thinking and learning for every child. New York: The Free Press.

Pont, B., Nusche, D. and Hopkins, D. eds (2008) Improving school leadership, vol. 2: case studies on system leadership. OECD.

http://www.oecd.org/dataoecd/32/57/44375122.pdf (accessed 15 Sept 2011). Ravitch, D. (2010) The death and life of the great American school system. New York: Basic Books.

Robbins, P and Aydede, M. eds. (2009) The Cambridge handbook of situated cognition. Cambridge: Cambridge University Press.

Salomon, G. ed. (1993) Distributed cognitions: psychological and educational considerations. Cambridge: Cambridge University Press.

Sefton Green J., Thomson, P., Jones, K, and Bresler, L eds. (2011) The Routledge international handbook of creative learning. London: Routledge.

Sennett, R. and Cobb, J. (1972) The hidden injuries of class. New York: Norton. Slee, R. (2011) The Irregular School: Exclusion, schooling and inclusive education. London: Routledge.

Thomson, P. (2001) How principals lose 'face': a disciplinary tale of educational administration and modern managerialism. Discourse, 22(1), 5-22. 
Thomson, P. (2002) Schooling the rustbelt kids: making the difference in changing times. Crows Nest: Allen and Unwin.

Thomson, P. and Blackmore, J. (2006) Beyond the power of one: redesigning the work of schools and their principals. Journal of Educational Change, 7(3), 161177.

Unger (2005) What should the Left propose? London: Verso.

Vygotsky, L. (1978) Mind in society: the development of higher psychological processes. Cambridge, MA: Harvard University Press.

Wrigley, T. (2003) Schools of hope: a new agenda for school improvement. Stoke on Trent: Trentham Books.

Wrigley, T. (2006a) Another school is possible. London: Bookmarks.

Wrigley, T. (2006b) Opening the text - voicing the future. In R White and $\mathrm{K}$ Cooper (2006) The practical critical educator: critical inquiry and educational practice. Rotterdam: Springer.

Wrigley, T., Thomson, P. and Lingard, B. (eds) (2012) Changing schools: alternative ways to make a world of difference. London: Routledge. 